\title{
Introduction to the Tafel V-bis Dataset: Death Duty Summary Information for The Netherlands, 1921
}

\section{Social and Economic History}

\author{
A. de Vicq \\ Utrecht University, Utrecht, Netherlands \\ a.devicq@uu.nl \\ R. Peeters \\ Utrecht University, Utrecht, Netherlands \\ r.l.m.peeters@uu.nl
}

\begin{abstract}
This article introduces a newly constructed dataset (i.e. the Tafel v-bis Dataset) containing summary information for all Dutch citizens who died in 1921 and were subject to inheritance taxation. This dataset provides personal and socio-economic information on 24,263 individuals, including their total wealth, age, profession, residence and marital status at their time of death. Consequently, this dataset can be useful for researchers stemming from various academic disciplines. The article first discusses the range of possible uses of the dataset. Then the authors explain how they constructed the dataset and provide the necessary criticism regarding the underlying source material. The dataset is available via the Utrecht University data platform, YODA.
\end{abstract}

\section{Keywords}

wealth - inheritance - specific statistics - downloadable

- Related data set "Tafel v-bis Dataset” with Do I www.doi.org/10.24416/UU01 -QG9Q8B in repository "YODA" 


\section{Introduction}

The goal of this article is to introduce a newly constructed dataset (i.e. the Tafel v-bis Dataset) containing summary information for the entirety of the population of Dutch citizens who died in 1921 and were subject to inheritance taxation. This dataset has personal and socio-economic information on 24,263 individuals, which includes their total wealth, age, profession, residence and marital status at their time of death. Consequently, this dataset can be useful for researchers stemming from various academic disciplines. Sociologists and demographists with interest in history, for example, can explore the correlation between an individual's gender, their profession and their accumulated wealth over a lifetime. They could also trace the root of regional development and gentrification, or the deterioration of regions on the municipal level. Since there are very few sources that combine information about wealth and social variables, this dataset could help us better understand how social stratification functioned and where social classification systems such as Hisco or Hisclass (see Appendices A and B) can be improved. Genealogists, on the other hand, could find personal information on their ancestors which is unavailable elsewhere. Legal scholars can rely on this data and their underlying sources to gain a deeper understanding of notarial deeds and the system of inheritances. Finally and perhaps most fittingly, (economic) historians can use this data to draw a very detailed picture of the distribution of wealth in the Netherlands in the early twentieth century (Bos, 1989; de Vries, 1986; Moes, 2012; van der Burg \& Rhoen, 2005; Wilterdink, 2015).

The interest in inequality has recently increased. Most notably are the works by Piketty (2014) and Piketty et al. (2006, 2014) about wealth inequality in the Western world and Paris in particular. Nonetheless, the availability of data, especially historical data, has not appeared to follow suit. Moreover, very few individual-level data are available on a national scale. We partially fill this gap for the Netherlands by constructing a database based on a source that brings together both financial and non-financial information on an individual level. To do this, we have selected the memories van successie or death duty forms which result from the levying of death duties on estates. These were customary in some of the Dutch Republic's provinces from the late seventeenth century onward and nationwide from 1818 to 1927 (Bos, 1989). These series are continuous and publicly accessible in the Dutch regional archives, and are readily available on paper, microfilm or online.

This article proceeds as follows. In section two we provide a detailed description of the dataset. We first describe the process through which the original source was created and apply source critique to the administrative 
procedure, particularly paying attention to the correctness of the wealth variables. Then we explain how we transcribed the source and how we constructed the dataset and give a brief explanation of how the extra wealth class variable was created.

\section{Description of the Dataset}

- Tafel v-bis Dataset deposited at the Utrecht University data platform YODA - DOI:Www.doi.org/10.24416/UUo1-QGgQ8B

- Temporal coverage: 1921 (1 January - 31 December)

The Tafel v-bis Dataset contains the information on all persons who died between 1 January 1921 and 31 December 1921 in the Netherlands and who were subject to inheritance taxation. This was about one-third of the ca. 66,0oo deceased of 1921 (Centraal Bureau voor de Statistiek, 1921). This source, bureaucratically known as Tafel v-bis (Table Five-bis) is, in fact, a ledger containing references to and summary information of the underlying death duties, in Dutch called memories van successie. The memories formed the basis of the Dutch inheritance taxation system between 1818 and 1927. The Tafel v-bis exists as a complementary source to the memories since 1856 . The Tafel v-bis is organized in a ledger per tax office (kantoor) and lists every individual for whom a memorie was drawn up in, organized per letter, and a summary description of personal information. The ledgers are currently held in the respective regional branches of the Dutch National Archive. Our database consists of a transcription of all ledgers of death duties for 1921, not the individual underlying death duties.

We have chosen the year 1921 because it is the year following the national census of 1920 (dated $3_{11}$ December 1920). The census data gives us a clear overview of the country, its population, age distribution and employment on a local level. Unfortunately, since individual-level census information is no longer available, we cannot connect both sources. Nonetheless, the overview on a more aggregate level does tell us more about specific biases in our dataset. The most notable bias by far is the age bias. The individuals in our dataset are notably older than the general Dutch population, and slightly older than the people who passed away in the Netherlands in 1921.

Moreover, the individuals in the dataset represent the right tail of the national wealth distribution. Figure 2 visualizes the distributions. We only capture the wealthiest $20 \%$ of the group of deceased. The dotted line represents the 1,000 guilder cutoff point. The Gini-coefficient for the Tafel v-bis dataset is 0.852 . 


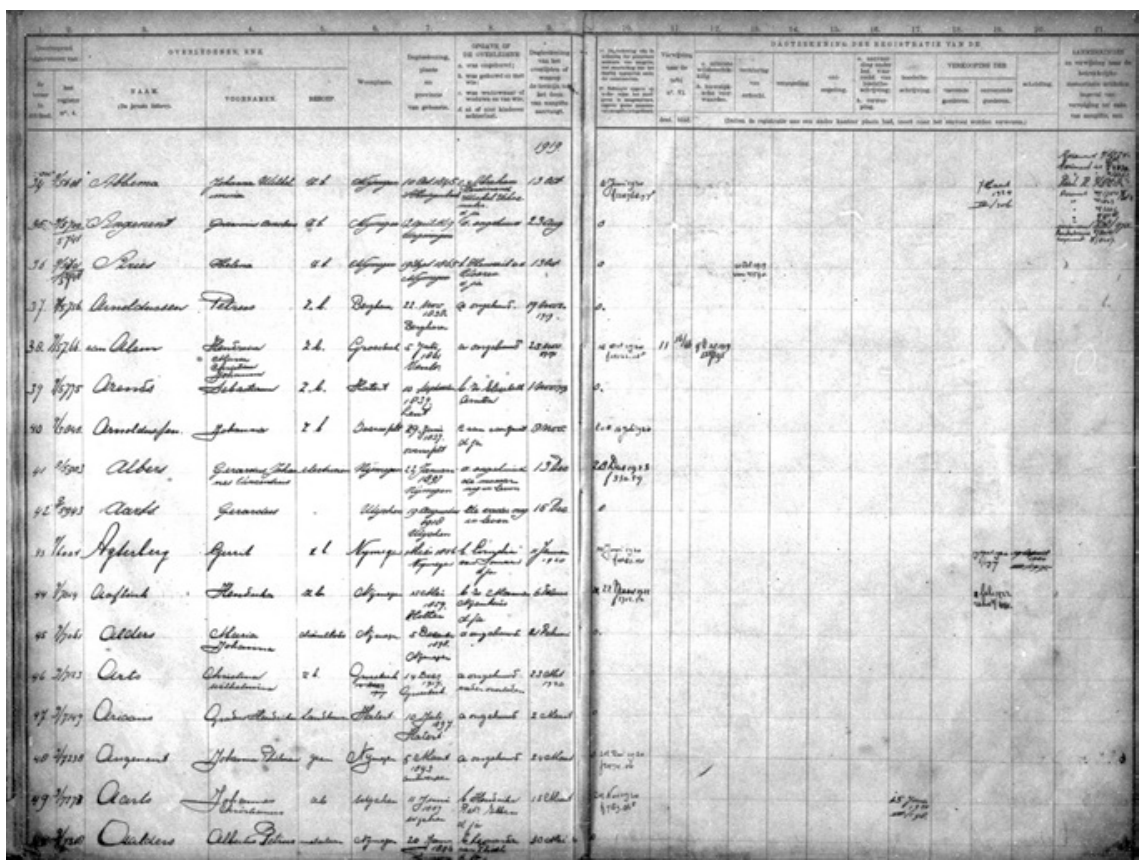

FIGURE 1 Example of the Tafel $v$-bis

GELDERS ARCHIEF, 0034 MEMORIES VAN SUCCESSIE, KANTOOR NIJMEGEN, 2.T28 1919-1921, PICTURE 006

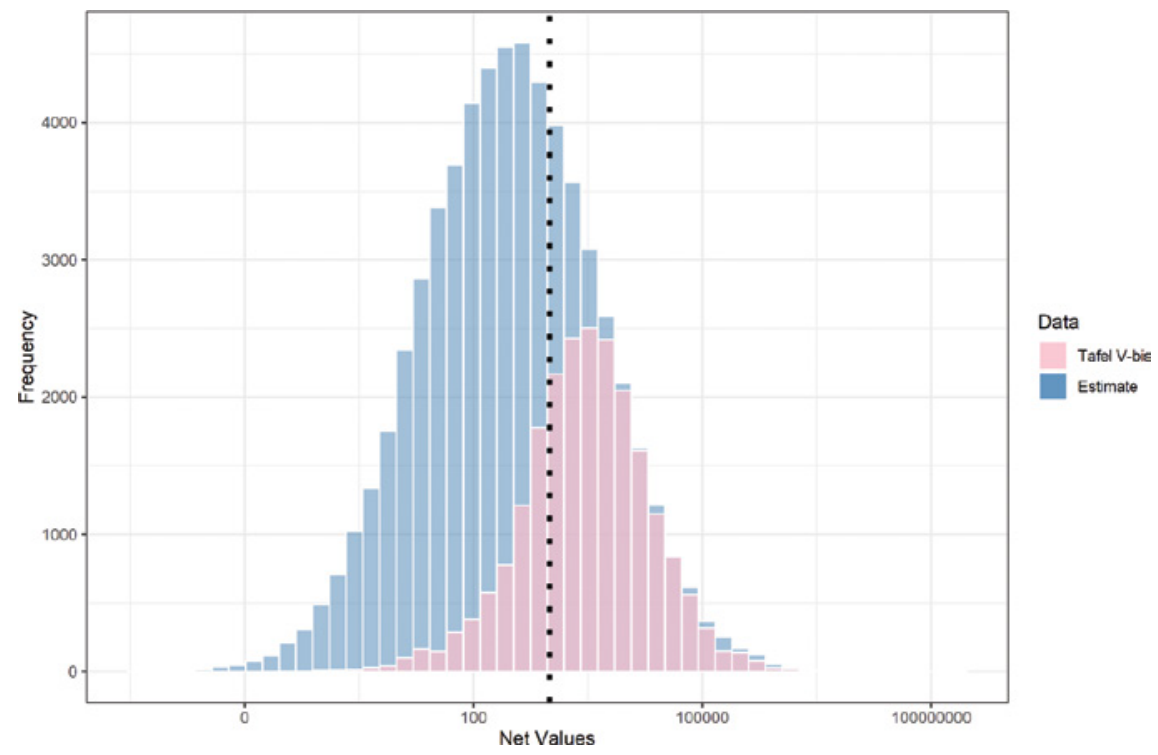

FIGURE 2 Wealth Distribution Population of Deceased and Tafel V-bis 


\section{Creation of the Source}

For a good understanding of the dataset and a critical assessment of its possible applications, we must pay attention to the administrative process that created the underlying source. In particular, our accuracy of the wealth variable depends on the quality of the underlying memorie.

The format of a memorie is similar to the more frequently researched probate inventories (boedelinventaris) in that each memorie mentions the name of deceased and the heirs followed by a description of the composition and value of the inheritance, bequest or gift. In addition, it mentions the profession and place of birth and residence of the deceased and the degree of kinship between the deceased and their respective heirs. Further, it mentions whether there was a will or prenuptial agreement with the name and residence of the notary who underwrote the agreement and the date when this took place. Considering both have a clear impact on how the inheritance ought to be divided, this information is of great importance.

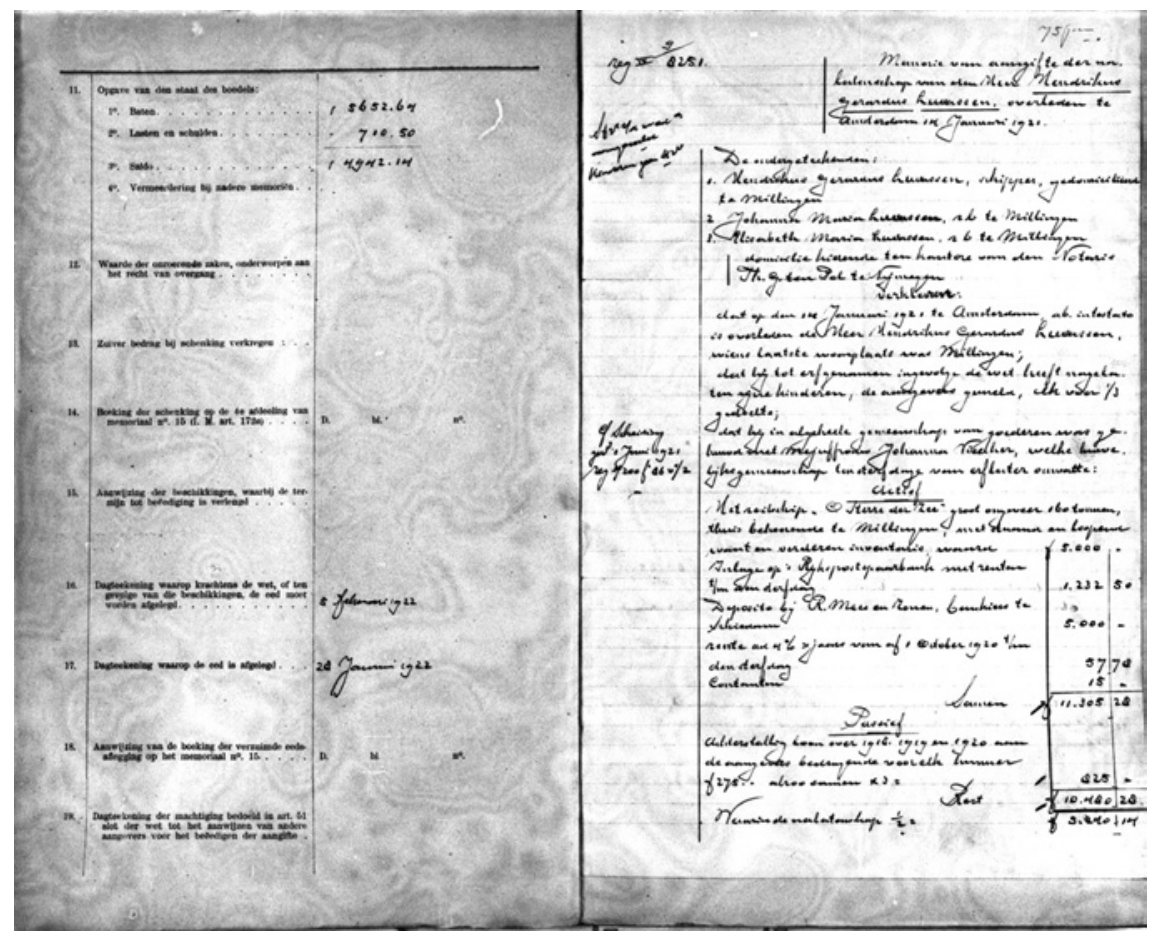

FIGURE 3 Example of a Memorie van Successie

GELDERS ARCHIEF, 0034 MEMORIES VAN SUCCESSIE, KANTOOR NIJMEGEN, 1.235 1921, PICTURE 12 
Each memorie provides a structured description of the inheritance and an estimate of the value of each individual asset. In the case of real estate, the nature, size, location, and cadastral registration numbers are also listed. Finally, each memorie also included a detailed account of the outstanding debt and accounts receivable of the deceased and the name of the counterparty.

The difference between memories and probate inventories is that memories were drawn up with the clear goal of taxing the estate, whereas probate inventories were compiled to, for example, safeguard the inheritance of minors or when people married (Wijsenbeek-Olthuis, 1995). This makes that, with memories, it was in the interest of the heirs not to register the whole inheritance to (illegally) lower taxes. The procedure, however, seems to have been relatively strict, leaving little room for such tax evasion.

Inheritances were only registered when they were subject to levies. Before 1878 , only estates with a net value larger than 300 guilders and when not all heirs were descendants in the direct line, were subject to the duty. Afterwards, every estate with a net value over 1,00o guilders had to pay the duty (Nationaal Archief, 2019). The broadening to all estates over a threshold, regardless of the relation of the heirs, greatly expanded the number of taxable estates. In 1921, every estate larger than 1,00o guilders was subject to the tax. Even corrected for inflation, the threshold went up. 300 guilders before 1878 consistently equalled between 2,000 and 3,000 2018 euro, whereas 1,000 guilders in 1878 is equal to roughly 10,000 2018 euro. Strong inflationary pressure during the First World War lowered the effective threshold for taxation, increasing the percentage of the population subject to taxation: 1,00o 1921 guilders equals ca. 6,500 2018 euro (Internationaal Instituut voor Sociale Geschiedenis, 2020).

Initially, Death Duties were drawn up by designated officials, usually municipal secretaries, known in Dutch as Secretaris van het plaatselijk bestuur, or Gequalificeerde tot de directie der invordering van de Belasting op het Regt van Successie. They were responsible for verifying the declarations made by families of the deceased at the house of the deceased - or sterfhuis in Dutch. Over time this procedure, which proved too much of an administrative burden, changed several times. From the 1900 onwards, representatives of the deceased (e.g. heirs, legatees, custodians, testamentary executors) were obliged to present a declarative statement to the municipal and/or cantonal office of the last place of residence of the deceased. This declaration had to be in written form and had to give insight into the nature and value of the inheritance. Everyone, including institutions and individuals exempted from taxation, had to file such a declaration (Zeeuws Archief, 2018). In case of the inheritance being worth less than 300 guilders, the heirs had to hand in a Certificate of 
Inability (Certificaat van Onvermogen), which they obtained from the municipality where the deceased resided.

This declaration had to be drawn up within six months after the time of death. Following this declaration, the heirs had one month (before 1911, two weeks) to take an oath in front of the District Court (Arrondissementsrechtbank) or the Subdistrict Court Judge (Kantonrechter), to certify that the provided information was correct. This official report (proces-verbaal) of the oathtaking had to be presented within four weeks to the civil servants in charge of the Death Duty and was attached to the declaration. Following this pledge, civil servants verified the declaration by cross-referencing the names and numbers of the deceased - based on a variety of sources, such as wealth and income taxes, at their disposal - within a given municipality or canton, with the individual names and the total number of declarations (Het Utrechts Archief, 2020). In the transitory period of six weeks, the corresponding levy was determined by the appropriate officials. Once the heirs were made aware of the amount due, they were given six weeks to resolve the outstanding levy.

Heirs were allowed to provide an additional supplementary declaration, socalled suppletoire aangifte, without any penalties in case of a further amendment to the initial declaration of inheritance. Usually, this happened at the insistence of the authorities. In case this was insufficient, or if the heirs did not cooperate, the authorities could go and estimate the value of the assets themselves. In case any fraud or tax evasion was detected, the authorities ordered a professional estimate of the inheritance and court proceedings could be started. Penalties were more or less twice the due tax plus costs of estimation (Zeeuws Archief, 2018). The effectiveness of these penalties was, of course, subject to the enforceability and ability to verify. Real estate was hard to hide and its value was easily verifiable using the cadaster, but the values of especially foreign and unlisted shares were much harder to establish. We can expect most fraud and tax-evasion to have taken place in these asset categories (Zeeuws Archief, 2018).

\section{Transcription of the Source}

A team of research assistants meticulously transcribed the Tafel v-bis of 1921 for the entire Netherlands. ${ }^{1}$ The following table gives an overview of all the variables in the dataset with their names, explanation and name in the original source. Every variable that was not in the original source is marked by an asterisk behind the name: 
TABLE 1 Overview of the Variables in the Dataset

\begin{tabular}{|c|c|c|}
\hline $\begin{array}{l}\text { Variable in } \\
\text { Dataset }\end{array}$ & $\begin{array}{l}\text { Description of the } \\
\text { Variable }\end{array}$ & $\begin{array}{l}\text { Column Number and } \\
\text { Original Name in the Source } \\
\text { (if applicable) }\end{array}$ \\
\hline ID* & Identification Number in the database & \\
\hline Ref_Reg & $\begin{array}{l}\text { Reference number to the underlying } \\
\text { memorie van succession. The original } \\
\text { source has “/” instead of “\#”. All “/" were } \\
\text { replaced to prevent import/conversion } \\
\text { errors. }\end{array}$ & $\begin{array}{l}\text { 2. Doorlopend volgnummer } \\
\text { van het register no. } 4\end{array}$ \\
\hline $\begin{array}{l}\text { Family_ } \\
\text { Name }\end{array}$ & Family Name of the deceased & 3. Naam \\
\hline First_Name & First Name of the deceased & 4. Voornamen \\
\hline
\end{tabular}

Gender* $\quad 0=$ male, $1=$ female, $\mathrm{GO}=$ unknown.

These were added on the basis of first names combined with information from the "Wie was wie" database. ${ }^{[a]}$ Whenever it was unclear GO was assigned. This process was fully manual.

Profession Profession of the deceased as listed by 5 . Beroep the heirs. Most likely this is the occupation at death.

Hisco* Hisco classification of the profession. This was manually assigned using the 2018 Hisco code book. ${ }^{[b]}$

Hiscam* Historical Camsis classification, based on Hisco. This was automatically converted to Hiscam L: Later period. c1890-1938, using a conversion script.

Hisclass* Historical Class Scheme, based on Hisco. This was automatically converted to Hisclass using a conversion script by Maas and van Leeuwen. ${ }^{[c]}$

[a] WieWasWie (http://wiewaswie.nl/).

[b] Mandemakers et al., 2018. See Appendix A for a description of Hisco.

[c] Maas \& van Leeuwen, 2016; van Leeuwen \& Maas, 2011. See Appendix B for a description of Hisclass. 
TABLE 1 Overview of the Variables in the Dataset (cont.)

\begin{tabular}{|c|c|c|}
\hline $\begin{array}{l}\text { Variable in } \\
\text { Dataset }\end{array}$ & $\begin{array}{l}\text { Description of the } \\
\text { Variable }\end{array}$ & $\begin{array}{l}\text { Column Number and } \\
\text { Original Name in the Source } \\
\text { (if applicable) }\end{array}$ \\
\hline Residence & $\begin{array}{l}\text { Place of residence of the deceased on } \\
\text { the municipal level }\end{array}$ & 6. Woonplaats \\
\hline Place_Birth & $\begin{array}{l}\text { Place of Birth of the deceased on the } \\
\text { municipal level }\end{array}$ & $\begin{array}{l}\text { 7. Dagteekening, plaats en } \\
\text { provincie van geboorte }\end{array}$ \\
\hline Age* $^{*}$ & $\begin{array}{l}\text { Age calculated based on year of birth } \\
\text { and year of death }\end{array}$ & \\
\hline Year_Birth & Year of birth of the deceased & $\begin{array}{l}\text { 7. Dagteekening, plaats en } \\
\text { provincie van geboorte }\end{array}$ \\
\hline $\begin{array}{l}\text { Month_ } \\
\text { Birth }\end{array}$ & Month of birth of the deceased & $\begin{array}{l}\text { 7. Dagteekening, plaats en } \\
\text { provincie van geboorte }\end{array}$ \\
\hline Day_Birth & Day of birth of the deceased & $\begin{array}{l}\text { 7. Dagteekening, plaats en } \\
\text { provincie van geboorte }\end{array}$ \\
\hline $\begin{array}{l}\text { Marital_ } \\
\text { Status }\end{array}$ & $\begin{array}{l}\text { Marital Status of the deceased. } \\
\mathrm{A}=\text { unmarried, } \mathrm{B}=\text { married, } \\
\mathrm{C}=\text { widow }(\mathrm{er}), \mathrm{D}=\text { has children or not }\end{array}$ & $\begin{array}{l}\text { 8. Opgave of de overledene: } \\
\text { a. was ongehuwd; b. was } \\
\text { gehuwd en met wie; c. was } \\
\text { weduwnaar of weduwe en } \\
\text { van wie; d. al of niet kinderen } \\
\text { achterlaat }\end{array}$ \\
\hline Divorced $^{*}$ & $0=$ no, $1=$ yes, blank=not listed & \\
\hline Children* & $\mathrm{o}=\mathrm{no}, \mathbf{1}=\mathrm{yes}$, blank=not listed & \\
\hline Year_Death & Year of death of the deceased & $\begin{array}{l}\text { 9. Dagteekening van het over- } \\
\text { lijden of waarop de termijn } \\
\text { tot het doen van aangifte } \\
\text { aanvangt }\end{array}$ \\
\hline $\begin{array}{l}\text { Month_ } \\
\text { Death }\end{array}$ & Month of death of the deceased & $\begin{array}{l}\text { 9. Dagteekening van het over- } \\
\text { lijden of waarop de termijn } \\
\text { tot het doen van aangifte } \\
\text { aanvangt }\end{array}$ \\
\hline
\end{tabular}


TABLE 1 Overview of the Variables in the Dataset (cont.)

\begin{tabular}{|c|c|c|}
\hline $\begin{array}{l}\text { Variable in } \\
\text { Dataset }\end{array}$ & $\begin{array}{l}\text { Description of the } \\
\text { Variable }\end{array}$ & $\begin{array}{l}\text { Column Number and } \\
\text { Original Name in the Source } \\
\text { (if applicable) }\end{array}$ \\
\hline Day_Death & Day of death of the deceased & $\begin{array}{l}\text { 9. Dagteekening van het over- } \\
\text { lijden of waarop de termijn } \\
\text { tot het doen van aangifte } \\
\text { aanvangt }\end{array}$ \\
\hline Net_Value & $\begin{array}{l}\text { Listed net value of the estate in } 1921 \\
\text { guilders (meaning gross wealth minus } \\
\text { liabilities, as stated in the memorie van } \\
\text { successie), cVo= Certificaat van Onver- } \\
\text { mogen (meaning the deceased was too } \\
\text { poor to pay taxes) }\end{array}$ & $\begin{array}{l}\text { 10. } 1^{\circ} \text { Dagteekening van de } \\
\text { indiening der primitieve } \\
\text { memorie van aangifte met } \\
\text { aanduiding van het daarbij } \\
\text { opgegeven saldo der nalaten- } \\
\text { schap } 2^{\circ} \text { Beknopte opgave op } \\
\text { welke wijze het sterfgeval is } \\
\text { aangezuiverd ingeval geene } \\
\text { memorie van aangifte is } \\
\text { ingediend }\end{array}$ \\
\hline
\end{tabular}

Kantoor* Administrative unit where the registration was made. There was a separate Tafel v-bis ledger per kantoor. In total there were 103 of such units.

VALIDnet- Dummy variable to indicate the quality value $^{*} \quad$ of the variable "Net_Value", $1=$ good, $\mathrm{o}=$ not fully trustworthy or unknown. This variable was added based on the comments made in the variable Info_ Logbook or Sum_Logbook.
VALID- Dummy variable to indicate the qual- name\& ity of the variables "Residence" and profession* "Place_Birth", $1=$ good, $0=$ not fully trustworthy or unknown. This variable was added based on the comments made in the variable Info_Logbook or Sum_Logbook.


TABLE 1 Overview of the Variables in the Dataset (cont.)

\begin{tabular}{lll}
\hline $\begin{array}{l}\text { Variable in } \\
\text { Dataset }\end{array}$ & $\begin{array}{l}\text { Description of the } \\
\text { Variable }\end{array}$ & $\begin{array}{l}\text { Column Number and } \\
\text { Original Name in the Source } \\
\text { (if applicable) }\end{array}$ \\
\hline
\end{tabular}

VALIDAge* Dummy variable to indicate the quality of the variable "Age", $1=$ good, $o=$ not fully trustworthy or unknown. This variable was added based on the comments made in the variable Info_Logbook or Sum_Logbook.

\begin{tabular}{|c|c|}
\hline Province* & $\begin{array}{l}\text { Province where the deceased resided, } \\
\text { based on the kantoor where the regis- } \\
\text { tration was made }\end{array}$ \\
\hline $\begin{array}{l}\text { Info_ } \\
\text { Logbook* }^{*}\end{array}$ & $\begin{array}{l}\text { Lists any comments made by the re- } \\
\text { search assistant who put in the data for } \\
\text { that line (mostly in Dutch) }\end{array}$ \\
\hline $\begin{array}{l}\text { Sum_- } \\
\text { Logbook* }^{*}\end{array}$ & $\begin{array}{l}\text { Lists any comments made by the re- } \\
\text { search assistant who put in the data for } \\
\text { that line (mostly in Dutch) }\end{array}$ \\
\hline Class* & 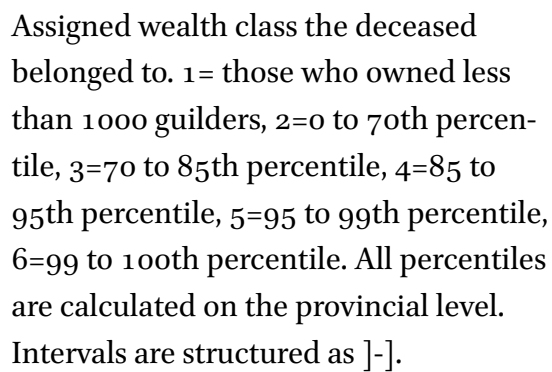 \\
\hline
\end{tabular}

Originally, the variables Day_Birth, Month_Birth, Year_Birth, and Place_Birth were listed in one entry in the source (column 9). For practical reasons, we have split this information into four variables. The variables indicating divorce and children were also mentioned in the source as part of the variable 
on marital status (column 8). We have split this information and coded it into dummy variables, again for practical reasons.

To keep track of ambiguities in the source and problems with the transcription of the source itself, such as illegible or confusing entries, the research assistants have noted this in the variables Info_Logbook and Sum_Logbook. Afterwards, we converted these comments into the dummy variables VALIDnetvalue, VALIDname\&profession and VALIDAge to indicate the quality of the entries.

The dataset is not a complete transcription of the source. We have not transcribed column 1 and columns 11 to 21 , which refer to other actions and documents. We were not interested in these actions and have not transcribed them. Also, only occasionally information was entered in these columns. We have photographs of them, which can be made available on request so that other researchers can expand the dataset if they need this information.

TABLE 2 Overview of the Non-Transcribed Variables from the Source

\begin{tabular}{|c|c|c|}
\hline $\begin{array}{l}\text { Column } \\
\text { Number }\end{array}$ & $\begin{array}{l}\text { Original Column Description } \\
\text { (Dutch) }\end{array}$ & $\begin{array}{l}\text { Translated Column Description } \\
\text { (English) }\end{array}$ \\
\hline 1 & $\begin{array}{l}\text { Doorlopend Volgnummer van de } \\
\text { letter in dit deel }\end{array}$ & $\begin{array}{l}\text { Continuous Tracking Number of } \\
\text { the Letter in this Ledger }\end{array}$ \\
\hline 11 & $\begin{array}{l}\text { Verwijzing naar de tafel } n^{\circ} \text { VI.: } \\
\text { Deel/blad }\end{array}$ & Reference to Tabel vi: Ledger/Page \\
\hline 12 & $\begin{array}{l}\text { Dagteekening der registratie van } \\
\text { de: a. uiterste wilsbeschikking. b. } \\
\text { huwelijksche voorwaarden }\end{array}$ & $\begin{array}{l}\text { Calendar date of the registration } \\
\text { of the: a. disposition of prop- } \\
\text { erty upon death. b. prenuptial } \\
\text { agreement }\end{array}$ \\
\hline 13 & $\begin{array}{l}\text { Dagteekening der registratie van } \\
\text { de: verklaring van erfrecht }\end{array}$ & $\begin{array}{l}\text { Calendar date of the registration } \\
\text { of the: declaration of right to } \\
\text { inherit }\end{array}$ \\
\hline 14 & $\begin{array}{l}\text { Dagteekening der registratie van } \\
\text { de: verzegeling }\end{array}$ & $\begin{array}{l}\text { Calendar date of the registration } \\
\text { of the: sealing }\end{array}$ \\
\hline 15 & $\begin{array}{l}\text { Dagteekening der registratie van } \\
\text { de: ontzegeling }\end{array}$ & $\begin{array}{l}\text { Calendar date of the registration } \\
\text { of the: de-sealing }\end{array}$ \\
\hline 16 & $\begin{array}{l}\text { Dagteekening der registratie van } \\
\text { de: a. aanvaarding onder het voor- } \\
\text { recht van boedelbeschrijving; b. } \\
\text { verwerping }\end{array}$ & $\begin{array}{l}\text { Calendar date of the registration } \\
\text { of the: a. acceptance under the } \\
\text { privilege of probate inventory; } b . \\
\text { rejection }\end{array}$ \\
\hline
\end{tabular}


TABLE 2 Overview of the Non-Transcribed Variables from the Source (cont.)

\begin{tabular}{lll}
\hline $\begin{array}{l}\text { Column } \\
\text { Number }\end{array}$ & $\begin{array}{l}\text { Original Column Description } \\
\text { (Dutch) }\end{array}$ & $\begin{array}{l}\text { Translated Column Description } \\
\text { (English) }\end{array}$ \\
\hline 17 & $\begin{array}{l}\text { Dagteekening der registratie van } \\
\text { de: boedelbeschrijving }\end{array}$ & $\begin{array}{l}\text { Calendar date of the registration } \\
\text { of the: probate inventory }\end{array}$ \\
\hline 18 & $\begin{array}{l}\text { Dagteekening der registratie } \\
\text { van de: verkooping der roerende } \\
\text { goederen }\end{array}$ & $\begin{array}{l}\text { Calendar date of the registration } \\
\text { of the: sale of the movable assets }\end{array}$ \\
19 & $\begin{array}{l}\text { Dagteekening der registratie van } \\
\text { de: verkooping der onroerende } \\
\text { goederen }\end{array}$ & $\begin{array}{l}\text { Calendar date of the registration } \\
\text { of the: sale of real estate }\end{array}$ \\
$\begin{array}{l}\text { Dagteekening der registratie van } \\
\text { de: } \text { scheiding }\end{array}$ & $\begin{array}{l}\text { Calendar date of the registration } \\
\text { of the: division }\end{array}$ \\
& $\begin{array}{l}\text { Aanmerkingen en verwijzingen } \\
\text { naar de betrekkelijke memoriaals } \\
\text { artikelen ingeval van vervolging ter } \\
\text { zake van aangifte enz. }\end{array}$ & $\begin{array}{l}\text { Comments and references to the } \\
\text { relative memoria and articles in } \\
\text { reporting, etc. }\end{array}$ \\
& &
\end{tabular}

\section{Construction of the Wealth Class Variable}

To get a better insight into the data and allow for more meaningful comparisons, we constructed six different wealth classes based on the provincial wealth distributions derived from the source (i.e. the Tafel v-bis). We discerned the following wealth classes:

1. Those who own less than 1000 f.: This class contains everyone that did not meet the official registration cut-off point. Probably these are people with high total assets, but also a lot of debts. We excluded them from the group for which we calculated the classes.

Besides, we have categorized the remaining population by their $\%$ of wealth:

1. [o to 7 oth] percentile

2. [70 to 85 th $]$ percentile

3. $[85$ to 95 th $]$ percentile

4. [95 to 99th] percentile

5. [99 to 1ooth] percentile 
The barriers to class are set per province and are thus relative to the provincial wealth distribution. The average cut off point for belonging to the provincial $1 \%$ is $328,796.55$ guilders. The lowest entry into the $1 \%$ class was in Limburg, where $83,05^{2}$ guilders sufficed. The highest entry point was in Utrecht, where you needed to own at least 742,281 guilders worth of assets. In Figure 2 above, we have provided a graphical overview of these cut-off points.

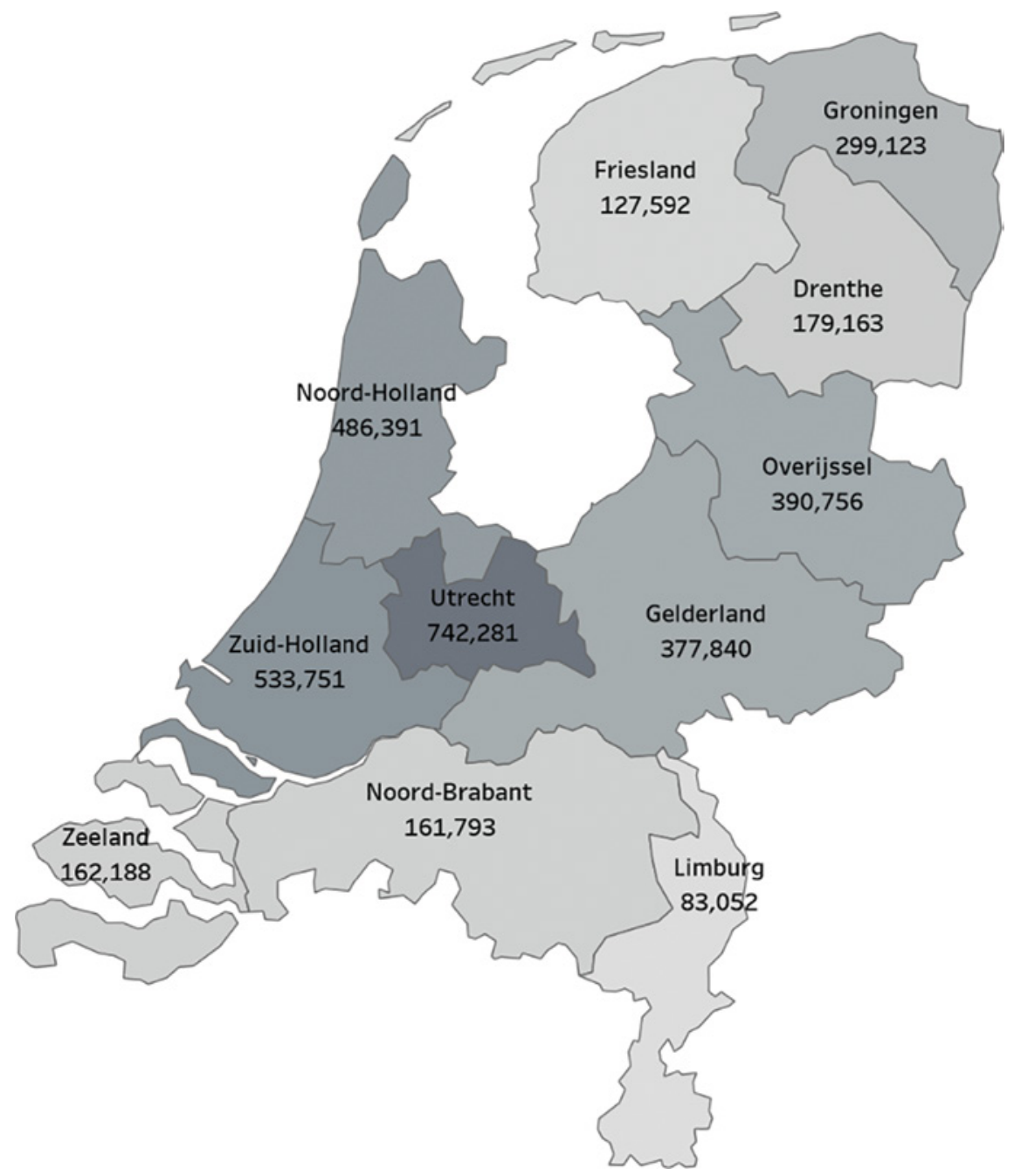

FIGURE 4 Wealth Distribution by Region

MAP BY PEETERS \& DE VICQ, BASED ON THE TAFEL V-BIS DATASET 
These numbers should not be compared with national estimates, because our threshold for belonging to the regional $1 \%$ is considerably higher than belonging to the national $1 \%$. It has to do with the inherent bias of only looking at people who pay inheritance taxes. The cut-off point for belonging to the national $1 \%$ in 1919 was around 80,000 guilders. When accounting for the number of people who are not in our dataset, we come to cut-off points comparable to the national ones. Counting the wealthiest $1 \%$ of the total Tafel v-bis data set, we arrive at a cut-off point of 108,945 guilders when not counting infants and minors $^{1}$ and 87,107 guilders when counting everyone who passed away. ${ }^{2}$

\section{Concluding Remarks}

This dataset is a first step in tapping this long-term source of high-quality information on wealth distributions linked to social variables. We are currently working with the Clariah project to link this dataset to civil registers and bring more data together on a personal level. We hope that this article will show the possibilities of this dataset and inspire other researchers to extend it to other years.

\section{Acknowledgements}

We thank Marlon Donck, Daan Hendrikx, Paul Schilder, Elien Van Dongen, Tirreg Verburg, and Guus Wieman for collecting and transcribing the data.

\section{References}

Bos, N. (1989). De memories van successie. Een veelbelovende bron voor veelsoortig onderzoek. Spiegel Historiael, 24, 120-126.

Centraal Bureau voor de Statistiek. (1921). Jaarcijfers voor Nederland voor het jaar 1921. de Vries, B. (1986). Amsterdamse vermogens en vermogensbezitters, 1855-1875. AAG Bijdragen, 12, 199-216.

Gelders Archief, 0034 Memories van Successie, Kantoor Nijmegen.

Internationaal Instituut voor Sociale Geschiedenis. (2020). De Waarde van de gulden / euro. http://www.iisg.nl/hpw/calculate-nl.php.

1 The 61oth wealthiest individual in the Tafel v-bis.

2 The 770 th wealthiest individual in the Tafel v-bis. 
Maas, I., \& van Leeuwen, M. H. D. (2016). Hisclass. (IISH Data Collection, V1). [Data set]. II Hs. https://hdl.handle.net/10622/HEFSW2.

Mandemakers, K., Mourits, R., \& Muurling, S. (2018). HSN_Hisco_release_2018_or (IISH Data Collection, V2). [Data set]. II Hs. https://hdl.handle.net/10622/MUZMAL.

Moes, J. (2012). Onder aristocraten. Over hegemonie, welstand en aanzien van adel, patriciaat en andere notabelen in Nederland, 1848-1914. Verloren.

Nationaal Archief. (2019). Memories van Successie Zuid-Holland (1806-1928). https:// www.nationaalarchief.nl/onderzoeken/zoekhulpen/memories-van-successie-zuid -holland-1806-1928\#collapse-7704.

Piketty, T. (2014). Capital in the twenty-first century (A. Goldhammer, Trans.). Harvard University Press.

Piketty, T., Postel-Vinay, G., \& Rosenthal, J.-L. (2006). Wealth concentration in a developing economy: Paris and France, 1807-1994. American Economic Review, 96(1), 236-256.

Piketty, T., Postel-Vinay, G., \& Rosenthal, J.-L. (2014), 'Inherited vs self-made wealth: Theory \& evidence from a rentier society (Paris 1872-1937). Explorations in economic history, 51(1), 21-40.

Het Utrechts Archief. (2020, March 31). Inventaris van het archief van de ontvanger der belastingen op het recht van successie. http://hetutrechtsarchief.nl/onderzoek/resul taten $/$ archieven $/$ ? mivast $=39 \& \mathrm{mizig}=210 \& \mathrm{miadt}=39 \& \mathrm{miaet}=1 \& \mathrm{cmicode}=337-1 \& \mathrm{cmin}$ $\mathrm{r}=5610053 \&$ miview $=$ inv2 \&milang $=\mathrm{nl}$.

van der Burg, V. A. M., \& Rhoen, R. P. M. (2005). De ontwikkeling van Zeist in de eerste helft van de negentiende eeuw met de memories van successie als historische bron. Seijst: bulletin ter bevordering van de kennis van de geschiedenis van Zeist, 35, 103-122.

van Leeuwen, M. H. D., \& Maas, I. (2011). Hisclass. A historical international social class scheme. Leuven University Press.

Wijsenbeek-Olthuis, T. F. (1995). Boedelinventarissen (Broncommentaren 2). Instituut voor Nederlandse Geschiedenis.

Wilterdink, N. (2015), Vermogensverhoudingen in Nederland: Ontwikkelingen sinds 1850. Van Gennep.

Zeeuws Archief. (2018, September 25). Ontvangers der Successierechten, (1795) 18061927. https://proxy.archieven.nl/o/1FEDA5C6798D49C3BoF9E8907F4F8707. 


\section{Appendix A}

Table A $\quad$ HIsco Tree of Occupational Groups ${ }^{[a]}$

\section{Major group o/1 Professional, technical and related workers}

Workers in this major group conduct research and apply scientific knowledge to the solution of a variety of technological, economic, social and industrial problems and perform other professional, technical, artistic and related functions in such fields as the physical and natural sciences, engineering, law, medicine, religion, education, literature, art, entertainment and sport.

\section{Major group 2 Administrative and managerial workers}

Workers in this major group conduct research and apply scientific knowledge to the solution of a variety of technological, economic, social and industrial problems and perform other professional, technical, artistic and related functions in such fields as the physical and natural sciences, engineering, law, medicine, religion, education, literature, art, entertainment and sport.

\section{Major group 3 Clerical and related workers}

Workers in this major group put into effect laws, rules and regulations made by central, state, provincial or local governments; supervise clerical and related work, transport and communications service operations; compile and maintain records of financial and other business transactions; handle cash on behalf of an organisation and its customers; record oral or written matter by shorthand writing, typing and other means; operate office machines and telephone and telegraph equipment; conduct passenger transport vehicles; take part in postal work and mail distribution and perform other duties related to the foregoing.

\section{Major group 4 Sales workers}

Workers in this major group are engaged in, or directly associated with, buying and selling goods and services of all kinds and in conducting wholesale and retail businesses on their behalf.

\section{Major group 5 Service workers}

Workers in this major group organise or perform catering, housekeeping, personal, protective and related services. 
Table A1 Hisco Tree of Occupational Groups (cont.)

Major group 6 Agricultural, animal husbandry and forestry workers, fishermen and hunters

Workers in this major group conduct farms on their behalf or in partnership, perform agricultural, animal husbandry and forestry tasks, catch fish, hunt and trap animals, and perform related tasks.

Major group 7-8-9 Production and related workers, transport equipment operators and labourers

Workers in this major group are engaged in or directly associated with the extraction of minerals, petroleum and natural gas from the earth and their treatment; manufacturing processes; the construction, maintenance and repair of various types of roads, structures, machines and other products. Also included are those who handle materials, operate transport and other equipment and perform labouring tasks requiring primarily physical effort.

[a] History of Work Information System. https://historyofwork.iisg.nl/index.php.

\section{Appendix B}

\section{HISCLASS}

HISCLASS is international historical class scheme, created for the purpose of making comparisons across different periods, countries and languages. Furthermore, it is linked to an international standard classification scheme for occupations - HISCO. HISCLASS is an instrument that can be used to systematically compare social class positions, distilled from a dazzling variety of occupational titles, around the world and over a range of periods. ${ }^{3}$

3 HISCLASs. http://www.hisma.org/HISMA/HISCLASS.html. 
TABLE A2 Description of Hisclass ${ }^{[a]}$

HISCLASS Description

1

2

3

4

6

7

8

9

10

11

12

[a] Mandemakers et al., 2018.

\author{
Higher managers \\ Higher professionals \\ Lower managers \\ Lower professionals, clericals and \\ salesmen \\ Lower clericals and salesmen \\ Foremen \\ Skilled workers \\ Farmers \\ Lower skilled workers \\ Lower skilled farm workers \\ Unskilled workers \\ Unskilled farm workers
}

